\title{
Brain and Plasma Riluzole Pharmacokinetics: Effect of Minocycline Combination
}

\author{
Aline Milane ${ }^{1}$, Lionel Tortolano ${ }^{1}$, Christine Fernandez ${ }^{1,2}$, Gilbert Bensimon ${ }^{3}$, Vincent Meininger ${ }^{4}$, Robert \\ Farinotti ${ }^{1,2}$
}

${ }^{1}$ Université Paris-Sud XI, Laboratoire de Barrières et Passage des Médicaments, EA 2706, Faculty of Pharmacy, Chatenay-Malabry, France ${ }^{2}$ Department of Pharmacy, Pitié Salpêtrière Hospital, Assistance Publique-Hôpitaux de Paris, Paris, France ${ }^{3}$ Department of Pharmacology, Pitié Salpêtrière Hospital, Assistance Publique-Hôpitaux de Paris and Université Pierre et Marie Curie (Paris-VI), Paris, France ${ }^{4}$ Department of Neurology, Pitié Salpêtrière Hospital, Assistance Publique-Hôpitaux de Paris, Paris, France.

Received December 12, 2008; Revised June 30, 2009; Accepted July 24, 2009; Published August 5, 2009.

\begin{abstract}
Purpose. Amyotrophic lateral sclerosis is a fatal neurodegenerative disease characterized by the loss of motorneurons. The only drug approved is riluzole. Minocycline is an antibiotic with numerous neuroprotective properties. riluzole and minocycline were given to an animal model of ALS and had beneficial effect on the disease. The combination was then tested in humans in phase II and phase III studies with less beneficial effects and a faster decline of the disease in the group treated with minocycline. In a previous study, we showed that riluzole is transported out of the brain by the P-glycoprotein at the bloodbrain barrier level. In this work, we tested the hypothesis of a drug-drug interaction between riluzole and minocycline. Methods. We studied in CF1 mice, the plasma and brain pharmacokinetics of riluzole combined or not with minocycline. Results. Our results showed that riluzole pharmacokinetics are not linear with dose, but that brain $\mathrm{AUC}_{0-\mathrm{t}}$ increase proportionally with plasma $\mathrm{AUC}_{0-\mathrm{t}}$. At the dose of $10 \mathrm{mg} / \mathrm{kg}$, the brain AUC0-t /plasma AUC0-t ratio was 4.6 in mdrla (-/-) mice and 2.4 in mdr1a (+/+) mice. The combination of minocycline $(170 \mathrm{mg} / \mathrm{kg})$ and riluzole $(10 \mathrm{mg} / \mathrm{kg})$ induced a 2 fold increase in the brain AUC0-t of riluzole and induced a neuromuscular toxicity in mice. This effect of minocycline was not found at low concentration $(10 \mathrm{mg} / \mathrm{kg}$ of minocycline). Conclusions. If our results are confirmed in humans, riluzole brain concentrations could be predicted by plasma concentrations. Furthermore, the combination of high doses of minocycline with riluzole could induce neurological toxicity that lead to deceiving results in ALS clinical studies. Hence, a dose-range of minocycline combined with riluzole should be tested in further clinical studies.
\end{abstract}

\section{INTRODUCTION}

Amyotrophic lateral sclerosis (ALS) is a fatal neurodegenerative disease characterized by progressive muscle weakness, muscle atrophy and paralysis (1-3). Riluzole is currently the only approved pharmacological treatment of ALS (4, 5). However, the clinical outcome of this compound is very modest. In recent studies, minocycline, a tetracyclic antibiotic, exhibited neuroprotective properties that led to preclinical and clinical studies (6-8).

In a mice model of ALS, the combination of minocycline, riluzole and creatine had beneficial effects on the disease progression and survival of mice (9). However, like many other molecules, after interesting results in animal studies, its efficacy was very limited in humans. In ALS patients, clinical trials testing minocycline (alone or in combination), were conducted in order to improve the efficacy of the treatment (10). Minocycline was first evaluated in pilot phase II studies in small groups of ALS patients (11). These trials were designed to test (1) the safety and tolerability of different doses of minocycline over prolonged periods in subjects taking riluzole and (2) doses of minocycline higher than the ones previously given, attempting to obtain the highest tolerable dosage. These trials were realised as feasibility studies for a larger phase III trial of efficacy. A multicenter randomized controlled trial was then conducted to establish the efficacy of minocycline in patients with ALS (10). This study is one of the first randomized controlled trials which test the efficacy of minocycline in patients with a neurological disorder.

Corresponding Author: Christine Fernandez, Laboratoire de Barrières et Passage des Médicaments, EA 2706, Tour D1, Faculty of Pharmacy, 5 rue JB Clement, 92296 ChatenayMalabry, France; E-mail: christine.fernandez@psl.aphp.fr 
In this study, minocycline had a harmful effect on the course of ALS: Patients had a decline in the ALSFRS-R score used to assess the effect of the drug. A dose higher than the usual clinical dose was given, but authors concluded that the outcome was not related to dose, adverse effects or interaction with riluzole. Like other recent trials in which drugs had no benefit or seemed to cause deterioration in patients with ALS, possibly owing to interactions between the drugs and riluzole or adverse events, this trial could not replicate in patients the positive findings from laboratory studies. In this study, interpretation of the results did not include any pharmacokinetic data or argument. Leigh et al. have suggested that either high minocycline doses were responsible for the toxic effects observed, or an interaction occurred between riluzole and minocycline at the blood-brain barrier (BBB) level, leading to increased brain concentrations of riluzole (12). Our paper addresses this last issue, testing the interaction between riluzole and minocycline at the BBB level.

The BBB restricts entry to the brain of xenobiotics because of very low paracellular (tight junctional) permeability and expression of potent multispecific efflux transporters. Together, they limit entry and thus efficiency of drugs targeted to brain diseases. Some efflux proteins (ABC or ATP Binding Cassette transporters) are expressed on the luminal membrane and are responsible for the extrusion of their substrates from the endothelial cells of the BBB back to the blood circulation (13, 14). In previous studies, we have tested interactions between minocycline, riluzole and the efflux pumps at the BBB level. We showed mainly that P-glycoprotein (P-gp), the most influent efflux transporter at the BBB level, effluxes minocycline and riluzole out of the brain back to blood. We also showed that minocycline could inhibit P-gp functionality (15). Our results combined with Gordon's study aroused the question of a potential pharmacokinetic drug-drug interaction between riluzole and minocycline that could prevent the beneficial effect of this drug combination.

In order to explore this interaction, we have performed a complete brain and plasma pharmacokinetic study of riluzole, combined or not with minocycline, in mice. We have also performed a rotarod test to study the effect of riluzole and minocycline combination on neuromuscular function.

\section{METHODS}

\section{Animals}

Female CF1 mdrla (+/+) and CF1 mdrla (-/-) mice (naturally defective in BBB P-gp) of 30-40 g were purchased from Charles River Laboratories (Wilmington, MA, USA). Mice had water and regular rodent chow. Animal manipulation followed current European Union regulations and all experiments were approved by an animal ethics committee. Mice were anesthetized with isoflurane and blood was collected by intracardiac puncture. After euthanasia, brains were collected and rinsed with $\mathrm{NaCl} 0.9 \%$ for further analysis. Plasmas and brains were stored at $-80{ }^{\circ} \mathrm{C}$ for further analysis.

\section{Reagents}

Minocycline (minocycline hydrochloride) and riluzole were provided by Sigma-Aldrich (Saint Quentin Fallavier, France). All the reagents used are of analytical and/or HPLC quality

\section{Preparation of the solutions}

\section{-Solutions for HPLC analysis}

Stock solutions of riluzole were prepared at 1 $\mathrm{mg} / \mathrm{ml}$ in Methanol:Water (50:50, v/v). Solutions were stored at $-20^{\circ} \mathrm{C}$ and were stable for at least 3 months.

\section{-Solutions for animal treatment}

For animal treatment, minocycline was dissolved in water and riluzole in Water:PropyleneGlycol $(50: 50, \mathrm{v} / \mathrm{v})$. Doses used to treat animals in our study were similar to those used in previous animal studies where riluzole and minocycline showed interesting pharmacological properties in $\operatorname{ALS}$ mice $(16,17)$.

\section{High performance liquid chromatographic analysis}

The HPLC system consisted of a 715 UltraWisp autosample injector (Waters, StQuentin en Yvelines, France), a Shimadzu ${ }^{\circledR}$ LC-10AS pump and a Shimadzu ${ }^{\circledR}$ UV detector (Shimadzu, CroissyBeaubourg, France). Separation was achieved at room temperature on a reversed-phase Symmetry Shield $5 \mu \mathrm{m}$ RP8 column $(250 \times 3 \mathrm{~mm}$, i.d. $)$ equipped with a Symmetry Shield $5 \mu \mathrm{m}$ RP8 precolumn (Waters, St-Quentin en Yvelines, France). The method was linear over the following 
ranges: $0.1-4 \mu \mathrm{g} / \mathrm{mL}$ in plasma and $0.5-20$ $\mu \mathrm{g} / \mathrm{mg}$ in brain. Intra-day and inter-day variabilities were always under $20 \%$. Inaccuracies were under $10 \%$. Recoveries were $80 \%$ in plasma and $75 \%$ in brain.

Riluzole was quantified in blood and brain using an HPLC/UV detection method already described in a previous study (18).

Brain concentrations were corrected in order to consider vascular concentrations in the brain, as in previous study (15).

\section{Brain and plasma pharmacokinetics of riluzole in CF1 mdr1a (+/+) mice}

CF1 mdr1a $(+/+)$ mice were divided into 3 groups (5, 10 or $20 \mathrm{mg} / \mathrm{kg}$ of riluzole; $27 \mathrm{mice} /$ group). They were given a single dose of riluzole by intraperitoneal route (i.p.). Blood and brain were collected at $0,5,10,15,30,45,60,90$ and 180 minutes after injection.

\section{Brain and plasma pharmacokinetics of riluzole in CF1 mdr1a (-/-) mice}

27 CF1 mdr1a (-/-) mice were given a single dose of riluzole $(10 \mathrm{mg} / \mathrm{kg})$ by intraperitoneal route (i.p.). Blood and brain were collected at $0,5,10$, $15,30,45,60,90$ and 180 minutes after injection.

\section{Brain and plasma pharmacokinetics of riluzole when given with minocycline to CF1 mdr1a $(+/+)$ mice \\ CF1 mdr1a (+/+) mice were divided into 4 groups (27 mice/group) receiving $10 \mathrm{mg} / \mathrm{kg}$ of riluzole with $0,10,90$ or $170 \mathrm{mg} / \mathrm{kg}$ of minocycline. Blood and brain were collected at at $0,5,10,15,30,45$, 60, 90 and 180 minutes after riluzole injection.}

\section{Evaluation of neuromuscular toxicity of riluzole/minocycline combination}

24 mice were divided into 3 groups ( 8 mice per group) and they were treated for five days with riluzole $(10 \mathrm{mg} / \mathrm{kg})$ or minocycline $(170 \mathrm{mg} / \mathrm{kg})$ or both. Motor impairment was evaluated the day 6 using the rotarod test. Each mouse was placed on a rod rotating at $16 \mathrm{rpm}$. The test began by training each mice 3 times for 1 minute each 10 minutes. 1 hour after the training session, mice received riluzole $(10 \mathrm{mg} / \mathrm{kg}), 25$ minutes later they were put on the rod. The time the mouse stayed on the rod until it fell off (during a 3 minutes interval) was recorded. Five minutes after the test (30 minutes after the injection), mice were killed. Blood and brain were collected for riluzole analysis.

\section{DATA ANALYSIS}

Maximun plasma concentrations (Cmax), times to reach maximum plasma concentrations (Tmax) and AUCs of average profiles were used for comparisons between mdr1a (-/-) and mdrla (+/+) animals. Cmax and Tmax were determined by visually inspecting the experimental data. AUCs were estimated by the trapezoidal rule for the $n-1$ subintervals from 0 to the last time point. We used the sample mean as the function height at the different time points.

To study the potential correlation between brain AUC and plasma AUC as well as between riluzole brain concentrations and time spent on the rod, we used the Pearson product-moment correlation method.

The method developed by Bailer for destructive sampling was used to compare the AUCs between the

two treatment groups [2]. The standard error of the mean concentrations $y_{i}$ at time $t_{i}$, denoted $\mathrm{sem}_{\mathrm{i}}$, was estimated as the empirical standard deviation divided by $\mathrm{r}_{\mathrm{i}}$. Thus, the standard error of the mean AUC was estimated according to the equation:

$$
\begin{aligned}
\mathrm{se}^{2}\left[\overrightarrow{\mathrm{AUC}}_{t_{0}}^{n}\right]= & {\left[0.5 \times\left(t_{1}-t_{0}\right) \times \mathrm{sem}_{0}\right]^{2} } \\
& +\sum_{i=2}^{n}\left[0.5 \times\left(t_{i}-t_{i-2}\right)\right]^{2} \\
& +\left[0.5 \times\left(t_{n}-t_{n-1}\right) \times \mathrm{sem}_{n}\right]^{2}
\end{aligned}
$$

The test for equality of the mean AUCs between treatments $\mathrm{A}$ and $\mathrm{B}$ was performed using the standard Wald statistic:

$$
z_{\mathrm{obs}}=\frac{\left[\overline{\mathrm{AUC}}_{A}-\overline{\mathrm{AUC}}_{B}\right]}{\left[\sqrt{\mathrm{se}^{2}}\left(\overline{\mathrm{AUC}}_{A}\right)+\mathrm{se}^{2}\left(\overline{\mathrm{AUC}}_{B}\right)\right]}
$$

Under the null hypothesis that the mean AUCs are equal, this statistic follows a normal distribution. The null hypothesis was rejected if |zobs| was greater than 1.96 . 


\section{RESULTS}

\section{Brain and plasma pharmacokinetics of riluzole in CF1 mdr1a (+/+) mice}

Plasma and brain kinetic profiles were similar for the three doses of riluzole tested $(5,10$ and 20 $\mathrm{mg} / \mathrm{kg}$ ). Intracerebral entry of riluzole was rapid (tmax 5-30 minutes in brain and plasma) and was directly dependant on plasma concentration (Figure 1). Riluzole was not detectable in both tissues after 24 hours. The relations between plasma and brain AUCs is shown in Figure 2, for each dose, in mdrla (+/+) and mdrla (-/-) mice. The ratio plasma AUC0-t/Dose was significantly different between the three doses of riluzole, showing a non-linearity of the relation between AUC0-t and the dose. The Pearson correlation showed that plasma and brain AUC0-t were correlated for the three tested doses of riluzole $\left(\mathrm{R}^{2}\right.$ $=0.99, \mathrm{p}<0.001)$ (Figure 3). Five minutes after high dose $(20 \mathrm{mg} / \mathrm{kg})$ injection of riluzole, animals exhibited adverse events such as posterior members paralysis, weakness and shaking. Pharmacokinetics parameters of riluzole are presented in Table 1.

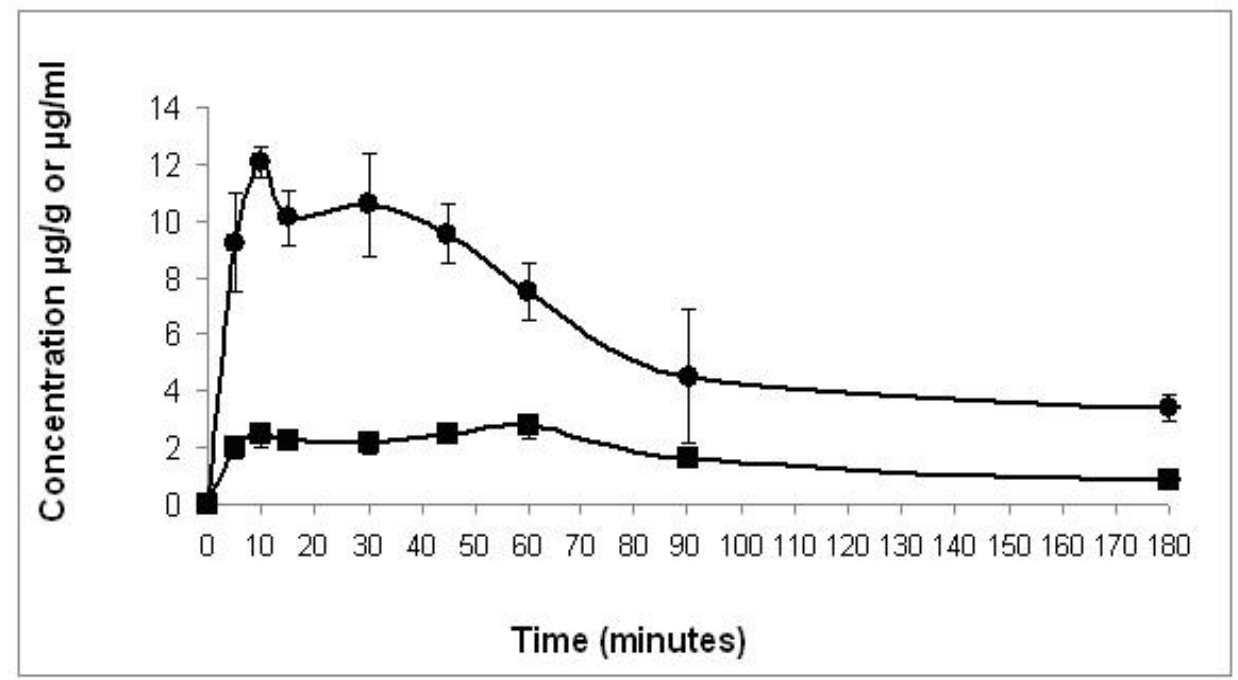

Figure 1. Plasma and brain pharmacokinetic profiles of riluzole given by i.p. route to CF1 mdr1a $(+/+)$ mice $(10 \mathrm{mg} / \mathrm{kg} ; \mathrm{n}=3$ mice per time, $\mathrm{m} \pm \mathrm{sd}$ ). (brain concentration (round shape) in $\mu \mathrm{g} / \mathrm{g}$ and plasma concentration (square shape) in $\mu \mathrm{g} / \mathrm{ml})$.

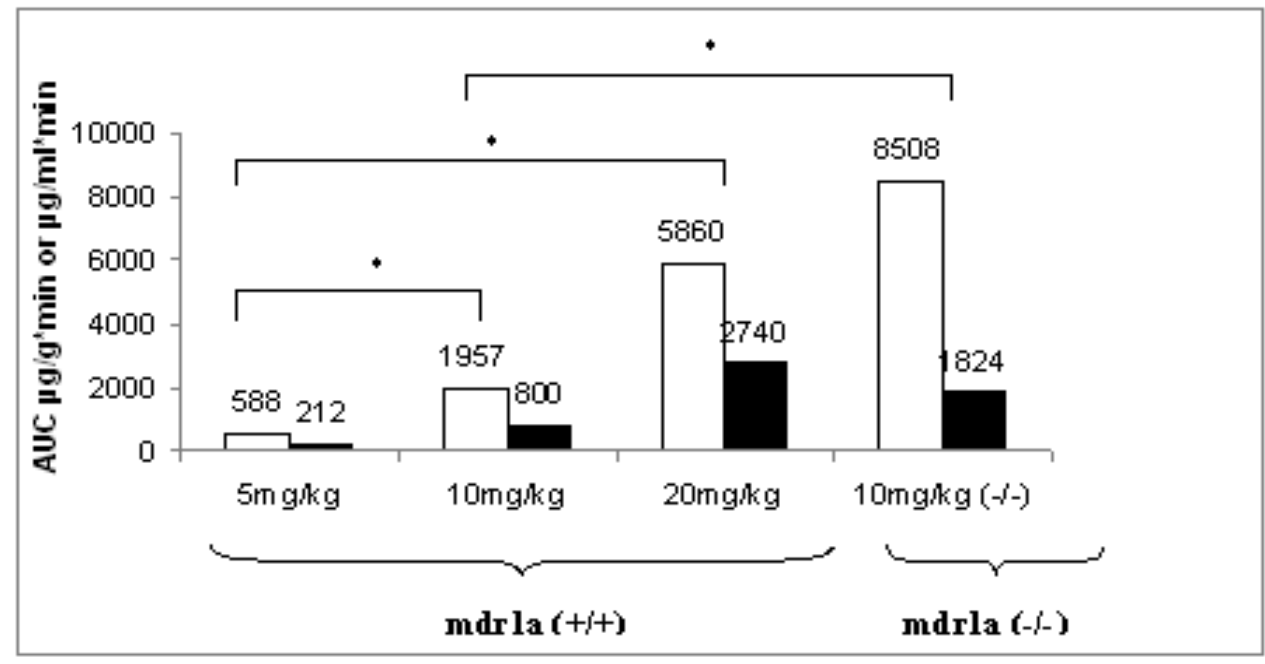

Figure 2. Brain and plasma $\mathrm{AUC}_{0-\infty}$ obtained after administration of riluzole $(5,10,20 \mathrm{mg} / \mathrm{kg})$ by i.p. route to $\mathrm{CF} 1$ mdrla $(+/+)$ mice and at $10 \mathrm{mg} / \mathrm{kg}$ by i.p. route to CF1 mdrla (-/-) mice ( $\mathrm{n}=27 \mathrm{mice} / \mathrm{dose})$ (Brain AUC ${ }_{0-\infty}$ (white shape) and plasma $\mathrm{AUC}_{0-\infty}$ (black shape)). 


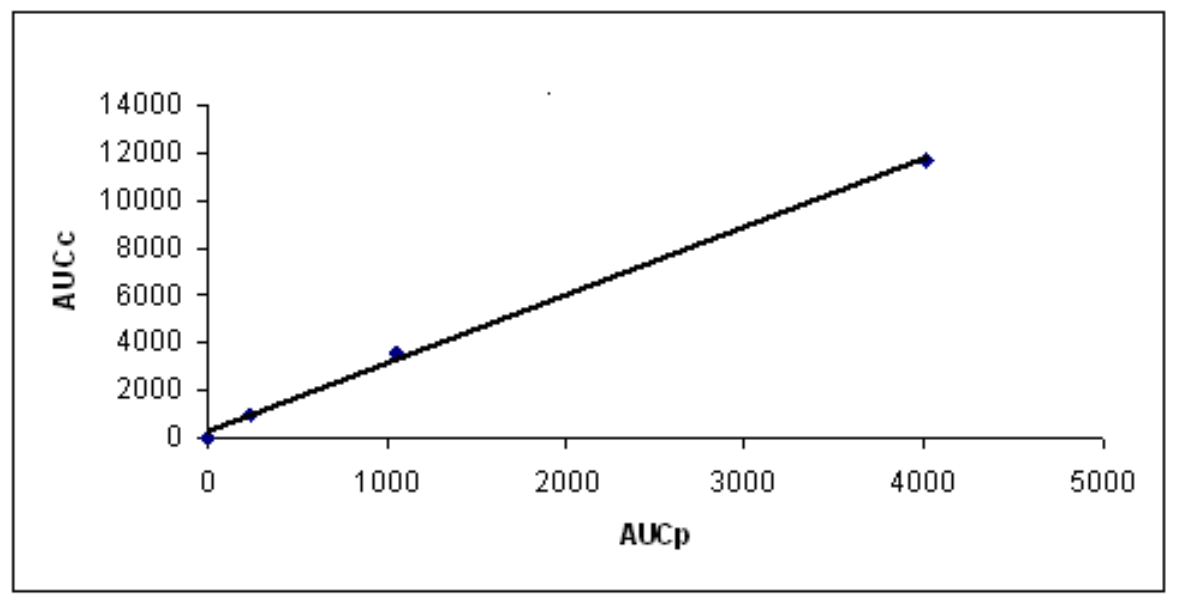

Figure 3. Correlation Scatter plot of brain AUC and plasma AUC for the three tested doses of riluzole $(5,10,20 \mathrm{mg} / \mathrm{kg})$

Table 1. Plasma and brain pharmacokinetic parameters of riluzole in CF1 mdrla(+/+) and mdr1a(-/-) mice after i.p. administration of different doses of riluzole $(n=27$ mice per dose)

\begin{tabular}{|c|c|c|c|c|c|}
\hline & & \multicolumn{3}{|c|}{ CF1 mdr1a $(+/+)$ mice } & \multirow{2}{*}{$\begin{array}{c}\text { CF1 mdr1a (-/-) mice } \\
10 \mathrm{mg} / \mathrm{kg}\end{array}$} \\
\hline & & $5 \mathrm{mg} / \mathrm{kg}$ & $10 \mathrm{mg} / \mathrm{kg}$ & $20 \mathrm{mg} / \mathrm{kg}$ & \\
\hline \multirow{5}{*}{ Plasma } & $\mathrm{Cmax}(\mu \mathrm{g} / \mathrm{ml})$ & 1 & 3 & 6 & 8 \\
\hline & $\operatorname{Tmax}(\min )$ & 15 & 60 & 45 & 10 \\
\hline & AUC0-t $\left(\mu \mathrm{g} / \mathrm{ml}^{*} \min \right)$ & 212 & 800 & 2740 & 1824 \\
\hline & $\mathrm{Cmax}(\mu \mathrm{g} / \mathrm{g})$ & 4 & 12 & 25 & 30 \\
\hline & $\operatorname{Tmax}(\min )$ & 10 & 10 & 30 & 10 \\
\hline Brain & AUC0-t $\left(\mu \mathrm{g} / \mathrm{g}^{*} \min \right)$ & 588 & 1957 & 5860 & 8508 \\
\hline
\end{tabular}

\section{Brain and plasma pharmacokinetics of riluzole in CF1 mdr1a (-/-) mice}

Pharmacokinetic parameters for CF1 mdr1a (-/-) are presented in Table 1. Plasma AUC0-t, brain AUC0-t and brain / plasma AUC0-t ratio were higher in CF1 mdr1a (-/-) mice when compared to CF1 mdrla $(+/+)$ mice $(\mathrm{p}<0.05)$ (Figure 2$)$. The brain /plasma AUC0-t ratio was 4.6 in mdrla (-/-) mice and 2.4 in mdrla $(+/+)$ mice.

Mdrla $(+/+)$ mice treated with $20 \mathrm{mg} / \mathrm{kg}$ and mdrla (-/-) mice treated with $10 \mathrm{mg} / \mathrm{kg}$ experienced same neurological adverse events that included: tremor, weakness and temporary member paralysis.

\section{Brain and plasma pharmacokinetics of riluzole when given with minocycline in CF1 mdr1a $(+/+)$ mice}

When combined with minocycline at $10 \mathrm{mg} / \mathrm{kg}$, no significant modification of riluzole brain pharmacokinetic parameters was observed. Conversely, when given with 90 and $170 \mathrm{mg} / \mathrm{kg}$ of minocycline, brain/plasma AUC0-t ratio of riluzole was significantly increased by 1.7 and 2.0 fold. Plasma riluzole AUC0-t was not significantly different between the four groups (Figure 4). Pharmacokinetics parameters of riluzole are presented in Table 2.

\section{Neuromuscular toxicity evaluation of riluzole/minocycline combination}

Motor impairment following mice treatment with riluzole/minocycline combination versus riluzole or minocycline alone was evaluated using the rotarod test. We observed that:

-Mice treated with riluzole alone stayed longer on the rod.

-The time spent on the rod was not significantly different between mincocyline and riluzole/minocycline groups. Minocycline did not increase the effect of riluzole on neuromuscular strength.

-The time spent on the rod was significantly decreased in the group treated for 5 days with the riluzole/minocycline combination compared to the group that received riluzole alone.

-The mean time spent on the rod per group was correlated with riluzole brain concentration $\left(\mathrm{R}^{2}=0.99, \mathrm{p}<0.0001\right)$ (Figure 5). 


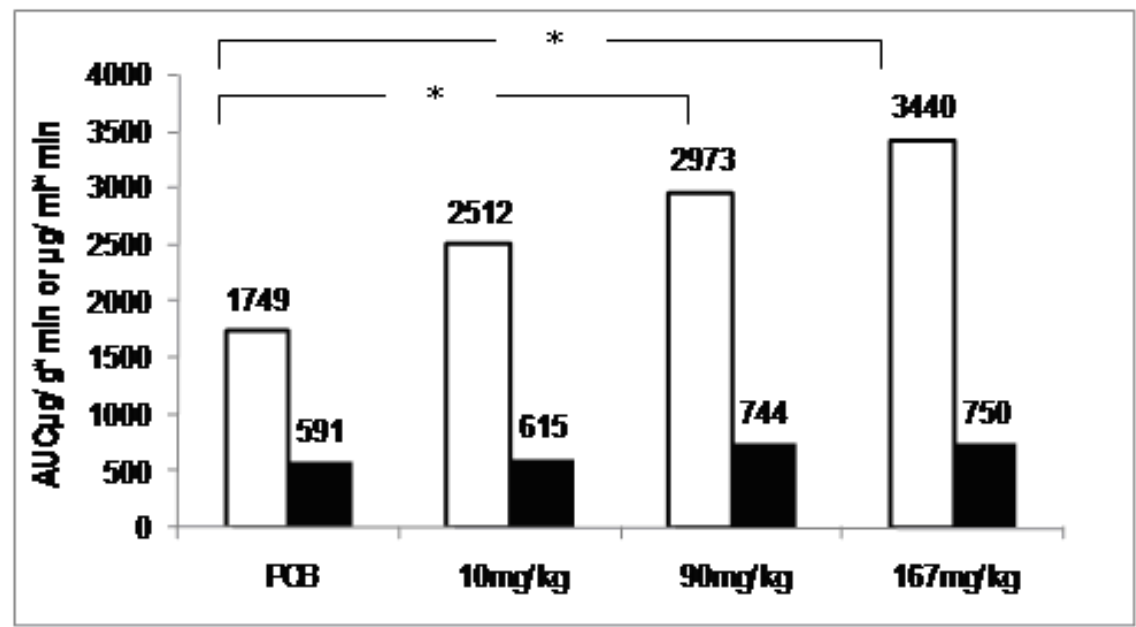

Figure 4. Brain and plasma AUC0-t of riluzole $(10 \mathrm{mg} / \mathrm{kg})$ when given by i.p. route with minocycline $(0,10,90 \mathrm{or} 170$ $\mathrm{mg} / \mathrm{kg}$ ) during 5 days.

Table 2. Plasma and brain pharmacokinetic parameters of riluzole $(10 \mathrm{mg} / \mathrm{kg})$ when given with minocycline by i.p. route $(\mathrm{n}=27$ mice per dose).

\begin{tabular}{|c|c|c|c|c|c|}
\hline & & \multicolumn{4}{|c|}{ Minocycline dose } \\
\hline & & Placebo & $10 \mathrm{mg} / \mathrm{kg}$ & $90 \mathrm{mg} / \mathrm{kg}$ & $170 \mathrm{mg} / \mathrm{kg}$ \\
\hline \multirow{4}{*}{ Plasma } & $\operatorname{Cmax}(\mu \mathrm{g} / \mathrm{ml})$ & 2.5 & 2.9 & 2.7 & 2.3 \\
\hline & $\operatorname{Tmax}(\min )$ & 5 & 5 & 30 & 30 \\
\hline & $\begin{array}{l}\text { AUC0-t } \\
\left(\mu \mathrm{g} / \mathrm{ml}^{*} \min \right)\end{array}$ & 591 & 615 & 744 & 750 \\
\hline & $\mathrm{Cmax}(\mu \mathrm{g} / \mathrm{g})$ & 12.5 & 10.6 & 11.1 & 16.6 \\
\hline \multirow[b]{2}{*}{ Brain } & Tmax (min) & 5 & 30 & 15 & 30 \\
\hline & $\begin{array}{l}\text { AUC0-t } \\
(\mu \mathrm{g} / \mathrm{g} * \min )\end{array}$ & 1749 & 2512 & 2973 & 3440 \\
\hline
\end{tabular}

\section{DISCUSSION}

The aim of this paper was to study the plasma and brain pharmacokinetics of riluzole in mice and to check the hypothesis of drug-drug interaction between riluzole and minocycline. This hypothesis could explain the negative results of a recent clinical study that combined riluzole and minocycline in ALS patients (10).

We have showed in these experiments, that combining riluzole to minocycline can enhance riluzole brain distribution and could be associated with central toxicity.

When given to mice, increasing doses of riluzole induced a non-proportional increase in plasma AUC0-t. This could be due to saturation of metabolism. As plasma and brain pharmacokinetic profiles were similar, brain penetration of riluzole seemed to be rapid and non saturable at observed plasma concentrations. We had previously reported elsewhere that riluzole brain distribution was dependent on P-gp activity (18). In this assay, the 2-fold increase of brain / plasma AUC0-t ratio in CF1 mdrla (-/-) mice when compared to CF1 mdrla (+/+) mice reconfirmed that P-gp transports riluzole out of the brain. P-gp plays a protective role of the brain against riluzole penetration: it does not completely stop riluzole from entering the brain but it prevents high toxic brain concentrations of riluzole. The absence of P-gp at the BBB level in mdr1a(-/-) mice increased riluzole brain penetration and induced neurotoxic effects (for a $10 \mathrm{mg} / \mathrm{kg}$ dose of riluzole) similar to those induced by high doses of riluzole $(20 \mathrm{mg} / \mathrm{kg})$ in mdrla $(+/+)$ mice. We did not expect any difference in plasma AUC between mdrla (-/-) and $(+/+)$ animals as P-gp does not interfere on transperitoneal transport. However, plasma AUC0-t were increased in CF1 mdr1a(-/-) mice. 

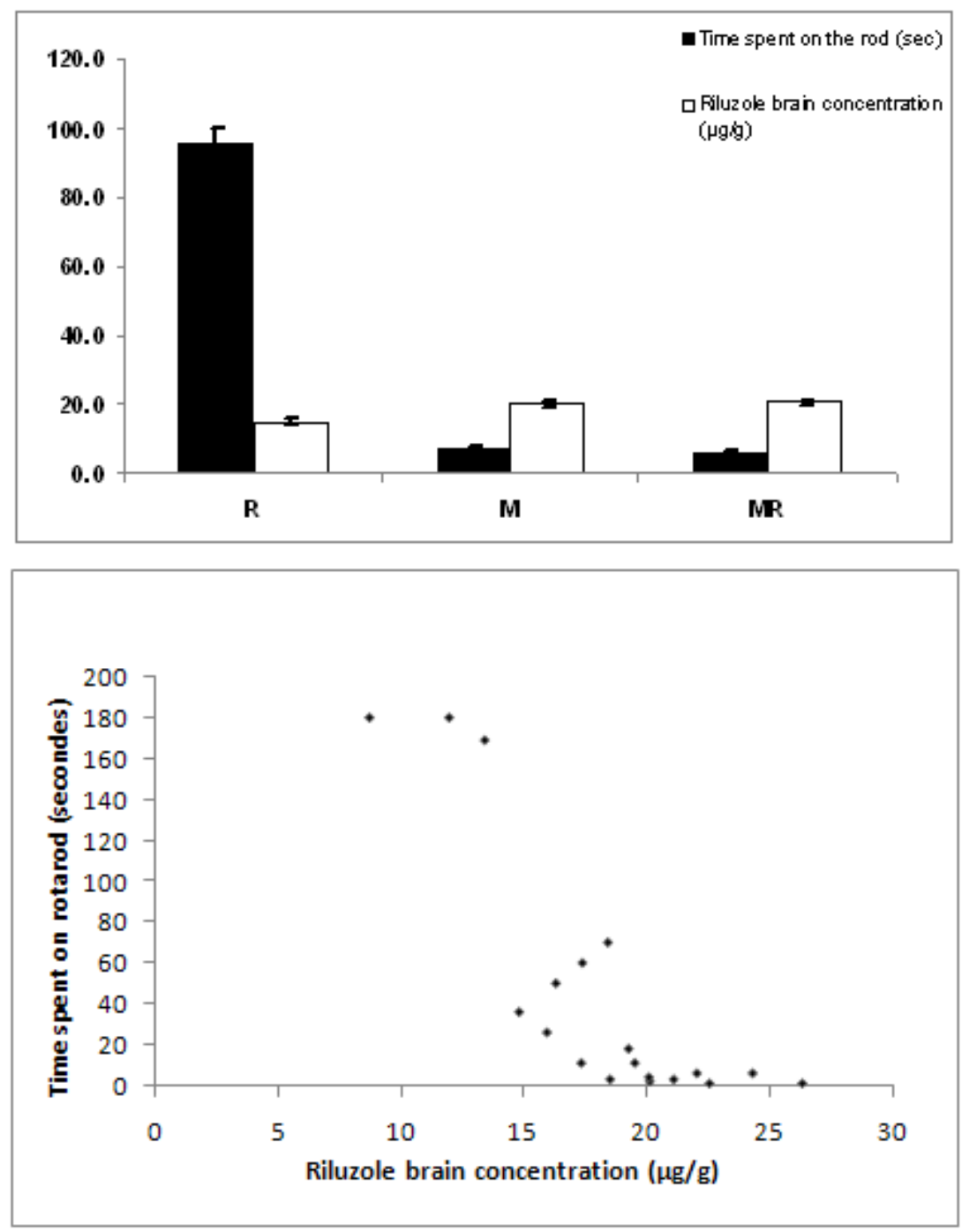

Figure 5. Rotarod test results and brain concentrations of riluzole after 5 day treatment of CF1 mdr1a $(+/+)$ mice with $10 \mathrm{mg} / \mathrm{kg}$ of riluzole, $170 \mathrm{mg} / \mathrm{kg}$ of minocycline or the combination riluzole/minocycline ( $\mathrm{m} \pm \mathrm{sd}$; time spent on the rod (white shape) in seconds; riluzole brain concentration (black shape) in $\mu \mathrm{g} / \mathrm{g}$ ).

This effect can be explained by a lower biliary excretion rate in P-gp deficient mice. This phenomenon was already reported by Kwei et al. who have reported that ivermectin and cyclosporin intestinal excretion are lower in mdrla (-/-) animals (19).

In wild-type mice, the increase of brain AUC0-t is proportional to plasma AUC0-t which means that efflux of riluzole is not saturated at the observed brain concentrations. Also, if pharmacological effect or toxicity of riluzole is correlated to brain concentrations in patients, plasma AUC0-t could be used to predict this brain concentrations and so efficacy or toxicity.
Such an hypothesis is supported by the results of Bensimon and Siniscalchi et al who showed that adverse neurological effects of riluzole, such as drowsiness, weakness, dizziness, are dose-dependent and could be correlated to brain concentrations $(20,21)$. Hence, any factor that increases brain concentrations of riluzole (overdosage, drug-drug interactions) could induce riluzole neurotoxicity. In patients, the increase of riluzole dose from $100 \mathrm{mg}$ to $200 \mathrm{mg}$ increased the risk of adverse effects as nausea, asthenia and hepatic transaminase elevation (5). In our study, in CF1 mdr1a(+/+) mice, the increase of dose up to $20 \mathrm{mg} / \mathrm{kg}$ induced high brain concentrations 
and toxic effects as ataxia, tremor, posterior limb paralysis.

Our work supports the hypothesis of an interaction between riluzole and minocycline which led to the negative effects of riluzole/minocycline combination. In a previous study, we have already shown that minocycline inhibits P-gp at the BBB level and leads to brain accumulation of P-gp substrates such as riluzole (15). In this study, we observed that the combination of minocycline with riluzole increases this latter brain $\mathrm{AUC} 0$ - $\mathrm{t}$ without modification of his plasma AUC0-t. This 2-fold increase of the brain/plasma AUC0-t ratio is equivalent to that observed in CF1 mdrla (-/-) mice when compared to CF1 mdrla (+/+) mice and so can be due to the inhibition of P-gp by minocycline.

This effect of minocycline on riluzole brain penetration was only observed with high doses of minocycline ( 90 and $170 \mathrm{mg} / \mathrm{kg}$ ) and not with the lowest dose $(10 \mathrm{mg} / \mathrm{kg})$. In humans, doses used are much less, around $6 \mathrm{mg} / \mathrm{kg}$. Gordon et al (10) have used the maximum tolerated doses of minocycline (up to 400 $\mathrm{mg} /$ day). Our assays showed that minocycline can be safe, giving no adverse effects by itself but can also enhance combined drug toxicity. However, Pontieri et al have shown that combined treatment with riluzole and minocycline at the dose of 100 $\mathrm{mg} /$ day (much lower than the $400 \mathrm{mg} /$ day dose tested in Gordon et al study (10)) did not induce significant side effects (22).

Hence, clinical studies with minocycline doses lower than $400 \mathrm{mg} /$ day should be performed before concluding definitively to treatment failure.

\section{AKNOWLEDGMENTS}

A Milane received a doctoral grant from the FRM Fondation Recherche Médicale

\section{REFERENCES}

[1]. D. W. Cleveland and J. D. Rothstein. From Charcot to Lou Gehrig: deciphering selective motor neuron death in ALS. Nat Rev Neurosci, 2:806-819, 2001.

[2]. J. P. Julien and J. M. Beaulieu. Cytoskeletal abnormalities in amyotrophic lateral sclerosis: beneficial or detrimental effects? J Neurol Sci, 180:7-14, 2000.

[3]. L. P. Rowland and N. A. Shneider. Amyotrophic lateral sclerosis. N Engl J Med, 344:1688-1700, 2001.
[4]. G. Bensimon, L. Lacomblez and V. Meininger. A controlled trial of riluzole in amyotrophic lateral sclerosis. ALS/Riluzole Study Group. N Engl J Med, 330:585-591, 1994.

[5]. L. Lacomblez, G. Bensimon, P. N. Leigh, P. Guillet and V. Meininger. Dose-ranging study of riluzole in amyotrophic lateral sclerosis. Amyotrophic Lateral Sclerosis/Riluzole Study Group II. Lancet, 347:1425-1431, 1996.

[6]. J. Yrjanheikki, T. Tikka, R. Keinanen, G. Goldsteins, P. H. Chan and J. Koistinaho. A tetracycline derivative, minocycline, reduces inflammation and protects against focal cerebral ischemia with a wide therapeutic window. Proc Natl Acad Sci U S A, 96:13496-13500, 1999.

[7]. M. Chen, V. O. Ona, M. Li, R. J. Ferrante, K. B. Fink, S. Zhu, J. Bian, L. Guo, L. A. Farrell, S. M. Hersch, W. Hobbs, J. P. Vonsattel, J. H. Cha and R. M. Friedlander. Minocycline inhibits caspase- 1 and caspase- 3 expression and delays mortality in a transgenic mouse model of Huntington disease. Nat Med, 6:797801,2000

[8]. R. O. Sanchez Mejia, V. O. Ona, M. Li and R. M. Friedlander. Minocycline reduces traumatic brain injury-mediated caspase-1 activation, tissue damage, and neurological dysfunction. Neurosurgery, 48:1393-1399; discussion 1399-1401, 2001.

[9]. J. Kriz, G. Gowing and J. P. Julien. Efficient three-drug cocktail for disease induced by mutant superoxide dismutase. Ann Neurol, 53:429-436, 2003.

[10]. P. H. Gordon, D. H. Moore, R. G. Miller, J. M. Florence, J. L. Verheijde, C. Doorish, J. F. Hilton, G. M. Spitalny, R. B. MacArthur, H. Mitsumoto, H. E. Neville, K. Boylan, T. Mozaffar, J. M. Belsh, J. Ravits, R. S. Bedlack, M. C. Graves, L. F. McCluskey, R. J. Barohn and R. Tandan. Efficacy of minocycline in patients with amyotrophic lateral sclerosis: a phase III randomised trial. Lancet Neurol, 6:1045-1053, 2007.

[11]. P. H. Gordon, D. H. Moore, D. F. Gelinas, C. Qualls, M. E. Meister, J. Werner, M. Mendoza, J. Mass, G. Kushner and R. G. Miller. Placebo-controlled phase I/II studies of minocycline in amyotrophic lateral sclerosis. Neurology, 62:1845-1847, 2004.

[12]. P. N. Leigh, V. Meininger, G. Bensimon, M. Cudkowicz and W. Robberecht. Minocycline for patients with ALS. Lancet Neurol, 7:119120; author reply 120-111, 2008.

[13]. D. J. Begley. Delivery of therapeutic agents to the central nervous system: the problems and the possibilities. Pharmacol Ther, 104:29-45, 2004. 
[14]. D. J. Begley. ABC transporters and the bloodbrain barrier. Curr Pharm Des, 10:1295-1312, 2004.

[15]. A. Milane, C. Fernandez, S. Vautier, G. Bensimon, V. Meininger and R. Farinotti. Minocycline and riluzole brain disposition: interactions with p-glycoprotein at the bloodbrain barrier. J Neurochem, 103:164-173, 2007.

[16]. J. Kriz, M. D. Nguyen and J. P. Julien. Minocycline slows disease progression in a mouse model of amyotrophic lateral sclerosis. Neurobiol Dis, 10:268-278, 2002.

[17]. J. Besheer, V. Lepoutre and C. W. Hodge. Preclinical Evaluation of Riluzole: Assessments of Ethanol Self-Administration and Ethanol Withdrawal Symptoms. Alcohol Clin Exp Res, 2009.

[18]. A. Maltese, F. Maugeri, F. Drago and C. Bucolo. Simple determination of riluzole in rat brain by high-performance liquid chromatography and spectrophotometric detection. J Chromatogr B Analyt Technol Biomed Life Sci, 817:331-334, 2005.

[19]. G. Y. Kwei, R. F. Alvaro, Q. Chen, H. J. Jenkins, C. E. Hop, C. A. Keohane, V. T. Ly, J. R. Strauss, R. W. Wang, Z. Wang, T. R. Pippert and D. R. Umbenhauer. Disposition of ivermectin and cyclosporin $\mathrm{A}$ in $\mathrm{CF}-1$ mice deficient in mdrla P-glycoprotein. Drug Metab Dispos, 27:581-587, 1999.

[20]. G. Bensimon and A. Doble. The tolerability of riluzole in the treatment of patients with amyotrophic lateral sclerosis. Expert Opin Drug Saf, 3:525-534, 2004.

[21]. A. Siniscalchi. [Tolerability of riluzole: a review of the literature]. Clin Ter, 155:25-28, 2004.

[22]. F.E. Pontieri, A. Ricci, C. Pellicano, D. Benicassa and F.R. Butarelli. Minocycline in amyotrophic lateral sclerosis : a pilot study. Neurol Sci, 26 :285-287, 2005. 